\title{
PENGARUH GAYA HIDUP TERHADAP KEPUTUSAN PEMBELIAN DAN KEPUASAN KONSUMEN SEPEDA MOTOR KAWASAKI D-TRACKER 150 DI KOTA DUMAI
}

\author{
Fajri Mubarak Natsir ${ }^{1}$, Zulkarnain ${ }^{2}$, Alvi Furwanti Alwie ${ }^{3}$ \\ ${ }^{1)}$ Mahasiswa Program Pascasarjana Universitas Riau \\ 2),3) Dosen Program Pascasarjana Universitas Riau \\ Email : fajrinatsir10@gmail.com ${ }^{1}$
}

\begin{abstract}
This study aims to see and know the direct and indirect effects of lifestyle on purchasing decisions and consumer satisfaction. The population in this study were 500 respondents from Dumai City who bought and used a Kawasaki D-Tracker 150 motorcycle, using Path Analysis. In this study the sampling method uses the Probability Sampling Technique, which is a sampling technique that provides equal opportunities for elements of the population to be selected as sample members. In this study the authors set a sample of the criteria of respondents, namely age 17 years and above. Samples taken in this study used the Slovin formula.

The results in this study that lifestyle has a positive and significant effect on consumer purchasing decisions. Lifestyle and purchasing decisions have a positive and significant effect on customer satisfaction. There is an indirect effect of Lifestyle on Consumer Satisfaction through Decisions.
\end{abstract}

Keywords: Lifestyle, Purchasing Decisions and Consumer Satisfaction

\section{PENDAHULUAN}

Dalam kondisi persaingan
yang semakin ketat, setiap perusahaan harus mampu bertahan hidup, bahkan harus dapat terus berkembang. Salah satu hal penting yang perlu diperhatikan dan dilakukan oleh setiap perusahaan adalah mempertahankan pelanggan yang telah ada, dan terus menggarap pelanggan-pelanggan potensial baru, agar jangan sampai pelanggan meninggalkan perusahaan dan menjadi perusahaan lain. Dengan kata lain perusahaan harus mampu mempertahankan loyalitas pelanggan (Lutiari, 2017). Perkembangan teknologi yang makin dinamis, manusia dituntut dengan cepat dan tepat agar tidak kalah bersaing. Persaingan dalam dunia bisnis kian ketat sehingga hal ini membuat para pelaku usaha arus berusaha demi memenangkan persaingan.

Untuk dapat bertahan perusahaan perlu merencanakan strategi pemasarannya. Hal yang mendasar dalam strategi pemasaran adalah pemahaman tentang konsep pemasaran, dimana kepuasan konsumen adalah titik sentralnya. Kepuasan terkait dengan kualitas produk atau jasa. Jadi untuk dapat bertahan dan mencapai tujuan perusahaan yang bersifat umum yaitu laba makan perusahaan perlu memperhatikan kualitas produk atau jasanya agar konsumen merasan puas, jadi disini 'nilai' kualitas dipandang dari sisi puas atau tidaknya konsumen. Memuaskan konsumen tidak lah mudah, karena bersifat relatif, untuk itu maka perlulah manajemen "memahami" 
konsumennya. Dalam literatur pemasaran agar dapat "memahami" konsumen biasanya manajemen perlu membuat suatu apa yang disebut dengan pemasaran sasaran.

Bidang transportasi muncul menjadi kebutuhan yang tidak lepas dari kehidupan manusia sejak dulu, hal ini disebabkan karena manusia sebagai makhluk yang mempunyai mobilitas diberbagai tempat. Selain itu perkembangan zaman saat ini menuntut manusia untuk dapat bergerak cepat dalam menjalankan segala aktifitas keseharian, menyebabkan adanya permintaan dan kebutuhan masyarakat akan sarana transportasi yang memadai. Pada dasarnya transportasi adalah perpindahan manusia dari satu tempat ke tempat lainnya, baik tanpa alat bantu maupun dengan alat bantu.

Berdasarkan data yang dihimpun dari AISI (Asosiasi Sepeda Motor Indonesia) berikut adalah total penjualan sepeda motor di Indonesia berdasarkan merek dan model pada tahun 2018.

Tabel 1.

Data Penjualan Sepeda Motor di Indonesia 2018

\begin{tabular}{|c|c|c|c|c|}
\hline Merek & Bebek & Sport & Skutik & Total \\
\hline Honda & 908.735 & 437.455 & 3.241 .470 & $\mathbf{4 . 5 8 7 . 6 6 0}$ \\
\hline Kawasaki & 3.151 & 232.871 & & $\mathbf{2 3 6 . 0 2 2}$ \\
\hline Suzuki & 384.788 & 6.103 & 84.522 & $\mathbf{4 7 5 . 4 1 3}$ \\
\hline TVS & 11.601 & 3.688 & 2.367 & $\mathbf{1 7 . 6 5 6}$ \\
\hline Yamaha & 623.762 & 718.809 & 1.249 .619 & $\mathbf{2 . 5 9 2 . 1 9 0}$ \\
\hline Total & $\mathbf{1 . 9 3 2 . 0 3 7}$ & $\mathbf{1 . 3 9 8 . 9 2 6}$ & $\mathbf{4 . 5 7 7 . 9 7 8}$ & $\mathbf{7 . 9 0 8 . 9 4 1}$ \\
\hline
\end{tabular}

Sumber: www.aisi.or.id 2019

Dari Tabel 1 diatas, bahwa Honda menguasai pasar sepeda motor di Indonesia, diikuti oleh Yamaha diperingkat 2, Suzuki diperingkat 3, Kawasaki diperingkat 4 dan terakhir TVS berada diperingkat 5. Terlihat jelas pasar sepeda motor yang ada pada beberapa merek anggota Asosiasi Industri Sepeda Motor Indonesia (AISI), memiliki beberapa produsen yang memiliki pangsa pasar Indonesia yang sangat besar dan terus bersaing, diantaranya Honda, Yamaha, Suzuki dan Kawasaki. Jenis sepeda motor ataupun tipe yang diproduksi di Indonesia pada dasarnya terbagi menjadi 3 jenis yaitu Motor Bebek,
Motor Skutik atau matic otomatis dan Motor Sport.

Persaingan sepeda motor jenis sport perlu mendapatkan perhatian, terutama konsumennya yang membutuhkan informasi yang akurat mengenai sepeda motor sport. Kawasaki D-Tracker merupakan produk sepeda motor sport dari PT Kawasaki Motor Indonesia (KMI) yang merupakan salah satu produk motor sport unggulan Kawasaki, produk tersebut sangat efektif dalam memasarkan produk melalui komunitas, mengingat segmen yang ingin dicapai yaitu kelas Premium dan Classy dengan target customer Pria, middle up, dan kalangan 
konsumen yang membutuhkan sepeda motor sebagai gaya hidup mewah (premium style), elegan, exsclusive, dan sporty.

Berdasarkan data yang diperoleh, berikut adalah total penjualan sepeda motor Kawasaki di Kota Dumai selama kurun waktu 2014-2018.

Tabel 2.

Penjualan Sepeda Motor Kawasaki di Kota Dumai 2014-2018

\begin{tabular}{|c|c|c|c|c|c|c|}
\hline \multirow{2}{*}{ Tipe } & \multicolumn{5}{|c|}{ Tahun } & \multirow{2}{*}{ Total (unit) } \\
\cline { 2 - 6 } & $\mathbf{2 0 1 4}$ & $\mathbf{2 0 1 5}$ & $\mathbf{2 0 1 6}$ & $\mathbf{2 0 1 7}$ & $\mathbf{2 0 1 8}$ & \\
\hline Athelete & 21 & 17 & 10 & 3 & 0 & $\mathbf{5 1}$ \\
\hline KLX 150 & 28 & 42 & 74 & 61 & 83 & $\mathbf{2 8 8}$ \\
\hline $\begin{array}{c}\text { D-Tracker } \\
\mathbf{1 5 0}\end{array}$ & $\mathbf{5 9}$ & $\mathbf{7 6}$ & $\mathbf{1 0 2}$ & $\mathbf{1 3 4}$ & $\mathbf{1 2 9}$ & $\mathbf{5 0 0}$ \\
\hline Ninja R & 97 & 102 & 81 & 63 & 45 & $\mathbf{3 8 8}$ \\
\hline Ninja RR & 56 & 33 & 62 & 48 & 31 & $\mathbf{2 3 0}$ \\
\hline Ninja 250R & 24 & 37 & 51 & 58 & 46 & $\mathbf{2 1 6}$ \\
\hline Total & $\mathbf{2 8 5}$ & $\mathbf{3 0 7}$ & $\mathbf{3 8 0}$ & $\mathbf{3 6 7}$ & $\mathbf{3 3 4}$ & $\mathbf{1 6 7 3}$ \\
\hline
\end{tabular}

Sumber: CV. Kawasaki Dumai 2019

terlihat bahwa puncak penjualan sepeda motor Kawasaki di Kota Dumai terjadi pada tahun 2016 yakni sebesar 380 unit dimana pada tahun itu D-Tracker 150 menjadi penjualan tertinggi yaitu sebesar 102 unit. Meski pada tahun seterusnya yakni tahun 2017 dan tahun 2018 total penjualan sepeda motor Kawasaki di Kota Dumai mengalami penurunan, namun penurunan yang terjadi tidak terlalu besar, bahkan pada tahun tersebut penjualan sepeda motor Kawasaki D-Tracker 150 meningkat tajam menjadi 134 unit dan pada tahun seterusnya CV. Kawasaki Dumai berhasil menjual 129 unit sepeda motor D-Tracker 150. Bahkan dari semua jenis motor yang dijual oleh CV. Kawasaki Dumai selama lima tahun terakhir, penjualan paling tinggi dipegang oleh sepeda motor jenis D-Tracker 150. Hal ini membutikan bahwa, sepeda motor
Kawasaki D-Tracker 150 menjadi pilihan utama masyarakat Dumai dalam membeli sepeda motor milik Kawasaki.

Keputusan pembelian adalah fungsi seberapa dekat harapan pembeli atas suatu produk dengan kinerja yang dirasakan pembeli atas produk tersebut. Jika kinerja produk lebih rendah daripada harapan pembeli, maka pembeli akan kecewa, dan jika sesuai dengan harapan, pembeli akan puas. Perasaanperasaan ini akan membedakan apakah pembeli akan membeli kembali produk tersebut. Keputusan pembelian merupakan pemikiran dimana individu mengevaluasi berbagai pilihan dan memutuskan pilihan pada suatu produk dari sekian banyak pilihan. Menurut Kotler \& Amstrong (2014), keputusan pembelian adalah tahap dalam proses pengambilan keputusan pembeli di 
mana konsumen benar-benar membeli.

Dengan mengetahui gaya hidup konsumen, pemasar dapat melakukan sesuatu kebijakankebijakan untuk dapat digunakan sebagai alat mengomunikasikan dan mendistribusikan produknya kepada konsumen agar dapat diterima dan digunakannya. Gaya hidup (life style) adalah adaptasi aktif individu terhadap kondisi sosial dalam rangka memenuhi kebutuhan untuk menyatu dan bersosialisasi dengan orang lain khususnya yang berkaitan dengan citra diri untuk merefleksikan status sosialnya. Terutama bagaimana dia ingin dipersepsikan oleh orang lain, sehingga gaya hidup sangat berkaitan dengan bagaimana ia membentuk image di mata orang lain berkaitan dengan status sosial yang disandangnya. Lifestyle (gaya hidup) merupakan konsep yang sangat penting dalam menganalisis tingkah laku gaya hidup pasar sasaran. Gaya hidup dimulai dengan mengidentifikasi tingkah laku (behavior) tentang minat, hasrat, dan pendapat para pasar sasaran. Kasalli (2015:225) menyatakan bahwa" Gaya hidup akan mempengaruhi keinginan seseorang untuk berperilaku dan akhirnya menentukan pilihan-pilihan konsumsi seseorang".

Didalam gaya hidup ada dimensi aktivitas yang meminta kepada konsumen untuk mengidentifikasikan apa yang mereka lakukan, apa yang mereka beli dan bagaimana mereka menghabiskan waktu mereka kerena mempunyai karakteristik pada diri konsumen dalam kehidupan sehariharinya. Aktivitas adalah apa yang mereka lakukan, apa yang mereka beli dan bagaimana mereka menghabiskan waktu mereka. Untuk melihat bagaimana gaya seorang atau pun sekelompok orang dapat diamati dari tempat tinggal maupun bentuk interaksi yang dilakukan setiap wargannya, baik dalam suatu perkampungan maupun lingkungan dimana si individu melakukan sutu interaksi. Interaksi yang dimaksud adalah interaksi yang dilakukan oleh satu individu dengan individu lain yang sangat dipengaruhi oleh perkembangan sikap dan perilaku individu tersebut. Dengan demikian sikap dan perilaku itu dapat membentuk suatu pola hidup yang khas dalam komunitas. Kehidupan yang demikian pada gilirannya akan memunculkan suatu bentuk gaya hidup.

Dimensi ketertarikan memfokuskan pada preferensi dan prioritas konsumen. Ketertarikan merupakan faktor pribadi konsumen dalam mempengaruhi proses pengambilan keputusan. Menyelidiki pandangan dan perasaan mengenai topik-topik peristiwa dunia, lokal, moral ekonomi, dan sosial.masyarakat, nilai-nilai dan sikapnya, tahap pembangunan ekonomi, hokum dan hubungannya. Opinion merupakan pendapat dari setiap konsumen yang berasal dari pribadi mereka sendiri. Solomon (2016), mengatakan bahwa opini dapat terdiri dari konsumen itu sendiri, isu sosial, isu politik, bisnis, ekonomi, pendidikan, produk, masa depan, dan budaya. Ekonomi dapat dan sedang berubah dengan cukup cepat.

\section{Kerangka Pemikiran}

Gaya hidup menurut Kotler (2012, p. 192) adalah pola hidup seseorang di dunia yang iekspresikan dalam aktivitas, minat, dan opininya. 
Gaya hidup menggambarkan "keseluruhan diri seseorang" dalam berinteraksi dengan lingkungannya.Gaya hidup menggambarkan seluruh pola seseorang dalam beraksi dan berinteraksi di dunia. Secara umum dapat diartikan sebagai suatu gaya hidup yang dikenali dengan bagaimana orang menghabiskan waktunya (aktivitas), apa yang penting orang pertimbangkan pada lingkungan (minat), dan apa yang orang pikirkan tentang diri sendiri dan dunia di sekitar (opini). Gaya hidup adalah perilaku seseorang yang ditunjukkan dalam aktivitas, minat dan opini khususnya yang berkaitan dengan citra diri untuk merefleksikan status sosialnya.

Keputusan pembelian adalah tindakan dari konsumen untuk mau membeli atau tidak terhadap produk. Dari berbagai faktor yang mempengaruhi konsumen dalam melakukan pembelian suatu produk atau jasa, biasanya konsumen selalu mempertimbangkan kualitas, harga dan produk sudah yang sudah dikenal oleh masyarakat Sebelum konsumen memutuskan untuk membeli, biasanya konsumen melalui beberapa tahap terlebih dahulu yaitu, (1) pengenalan masalah, (2) pencarian informasi. (3) evaluasi alternatif, (4) keputusan membeli atau tidak, (5) perilaku pascapembelian. Pengertian lain tentang Keputusan pembelian menurut Schiffman dan Kanuk (2000: 437) adalah "the selection of an option from two or alternative choice". Dapat diartikan, keputusan pembelian adalah suatu keputusan seseorang dimana dia memilih salah satu dari beberapa alternatif pilihan yang ada.

Menurut Philip Kotler dan Keller (2014), yang dikutip dari buku Manajemen Pemasaran mengatakan bahwa Kepuasan Konsumen adalah perasaan senang atau kecewa seseorang yang muncul setelah membandingkan kinerja (hasil) produk yang dipikirkan terhadap kinerja yang diharapkan. Memuaskan kebutuhan konsumen adalah keinginan setiap perusahaan. Selain faktor penting bagi kelangsungan hidup perusahaan, memuaskan kebutuhan konsumen dapat meningkatkan keunggulan dalam persaingan. Konsumen yang puas terhadap produk dan jasa pelayanan cenderung untuk membeli kembali produk dan menggunakan kembali jasa pada saat kebutuhan yang sama muncul kembali dikemudian hari. Hal ini berarti kepuasan merupakan faktor kunci bagi konsumen dalam melakukan pembelian ulang yang merupakan porsi terbesar dari volume penjualan perusahaan. Dari penjelasan dan permasalahan di atas dapat dibuat model penelitian sebagai berikut : 


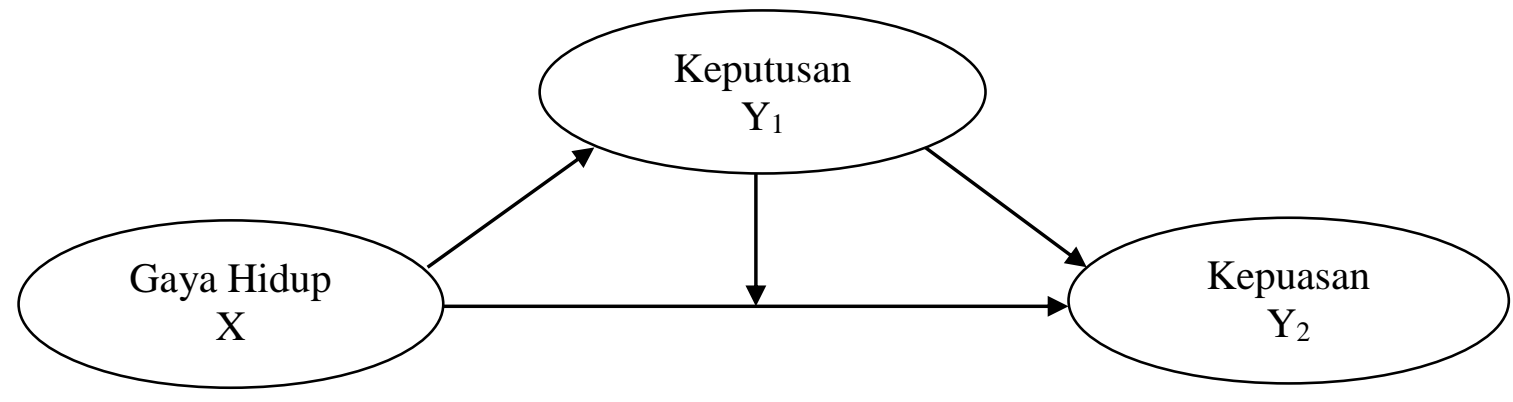

Gambar 1. Model Penelitian

Sumber : Modifikasi Merza Ariszani, 2015, Widayanto, 2013 dan Bashir, 2013

\section{Hipotesis}

Berdasarkan kerangka pemikiran, maka beberapa hipotesis untuk penelitian ini dipaparkan sebagai berikut:

H1: Gaya Hidup berpengaruh signifikan terhadap Keputusan Pembelian sepeda motor Kawasaki D-Tracker 150 di Kota Dumai.

H2: Gaya Hidup berpengaruh signifikan terhadap Kepuasan Konsumen sepeda motor Kawasaki D-Tracker 150 di Kota Dumai

H3: Keputusan Pembelian berpengaruh signifikan terhadap Kepuasan Konsumen sepeda motor Kawasaki DTracker 150 di Kota Dumai.

H4: Gaya Hidup berpengaruh signifikan terhadap Kepuasan Konsumen dengan Keputusan Pembelian sebagai mediasi pada sepeda motor Kawasaki D-Tracker 150 di Kota Dumai

\section{KERANGKA TEORI Kepuasan Konsumen}

Kepuasan adalah perasaan senang atau kecewa seseorang yang timbul karena membandingkan kinerja yang dipresepsikan produk (atau hasil) terhadap ekspektasi mereka (Kotler dan Keller, 2009). Hal tersebut ditambahkan kembali oleh Kotler dan Keller (2009) yaitu konsumen yang sangat puas biasanya akan tetap setia untuk waktu yang lebih lama, membeli lagi ketika perusahaan memperkenalkan produk baru dan memperbaharui produk yang lama, membicarakan hal-hal baik tentang perusahaan dan produknya kepada orang lain dan tidak terlalu sensitif terhadap harga.

$$
\text { Menurut Kotler dalam }
$$

Sunyoto (2013), kepuasan konsumen adalah tingkat perasaan seseorang setelah membandingkan (kinerja atau hasil) yang dirasakan dibandingkan dengan harapannya. Konsumen dapat mengalami salah satu dari tiga tingkat kepuasan umum yaitu kalau kinerja di bawah harapan, konsumen akan merasa kecewa tetapi jika kinerja sesuai dengan harapan pelanggan akan merasa puas dan apa bila kinerja bisa melebihi harapan maka pelanggan akan merasakan sangat puas senang atau gembira.

\section{Keputusan Pembelian (Purchasing Decisions)}

Amirullah

mengemukakan bahwa keputusan pembelian dapat didefinisikan 
sebagai suatu proses di mana konsumen melakukan penilaian terhadap berbagai alternatif pilihan dan memilih salah satu atau lebih alternatif yang diperlukan berdasarkan pertimbanganpertimbangan tertentu. Keputusan pembelian yang dilakukan oleh konsumen menggambarkan seberapa jauh tingkat pengaruh usaha pemasaran yang dilakukan terhadap suatu produk sehingga pemasar harus mengetahui perilaku konsumen dalam hal menentukan keputusan pembeliannya.

Ada beberapa tahap yang harus diperhatikan dalam membuat suatu proses pengambilan keputusan. Tahapan tersebut diawali dengan pengenalan kebutuhan, pencarian informasi, evaluasi alternatif, keputusan pembelian dan hasil pembeliankonsumen terhadap produk yang telah di beli. Menurut Kotler (2007), tahap-tahap proses keputusan pembelian adalah sebagai berikut:

1. Pengenalan Masalah

Proses pembelian diawali dengan adanya masalah atau kebutuhan kebutuhan yang belum terpuaskan dan dapat dirasakan oleh konsumen

Konsumen mempersiapkan perbedaan antara yang diinginkan dengan situasi saat ini guna membangkitkan dan mengaktifkan proses keputusan. Kebutuhan itu mungkin sudah dikenal dan dirasakan konsumen jauh-jauh dari sebelumnya.

2. Pencarian Informasi

Setelah konsumen menyadari adanya kebutuhan suatu barang atau jasa, selanjutnya konsumen mencari informasi, baik yang disimpan dalam ingatan maupun informasi yang didapat dari lingkungan luar. Sumber informasi konsumen digolongkan ke dalam empat kelompok, yaitu : (a) Sumber Pribadi : Keluarga, teman, tetangga, kenalan. (b) Sumber komersial : Iklan, wiraniaga, penyalur, kemasan. (c) Sumber Publik : Media massa, organisai penentu peringkat konsumen. (d) Sumber Pengalaman : Penanganan, pengkajian, pemakai produk

3. Evaluasi Alternatif

Setelah informasi diperoleh konsumen mengevaluasi berbagai alternatif pilihan dalam memenuhi kebutuhan tersebut

4. Keputusan Pembelian

Apabila tidak ada faktor lain yang mengganggu setelah konsumen menentukan pilihan yang telah ditetapkan, pembelian yang aktual adalah hasil akhir dari pencarian dan evaluasi.

5. Perilaku Pasca Pembelian

Secara umum, apabila individu merasakan ketertarikan yang sangat atau kepuasan dalam memenuhi kebutuhan, biasanya akan terus mengingat hal tersebut. Perilaku pasca pembelian meliputi kepuasan pasca pembelian, tindakan pasca pembelian, dan pemakaian produk pembelian.

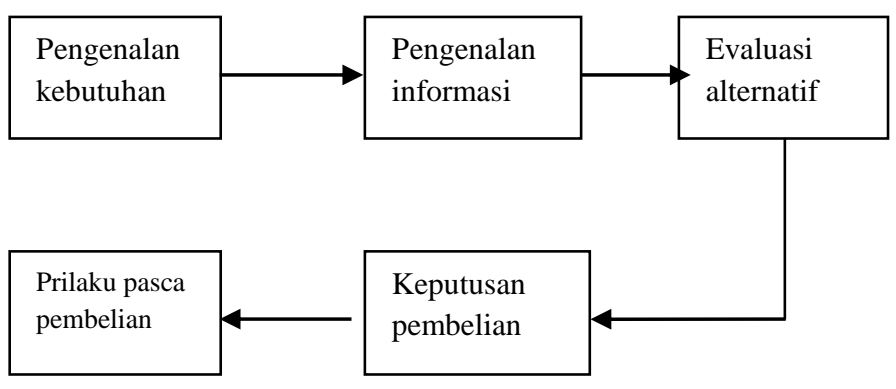

Sumber : Kotler (2011)

Gambar 2. Tahap-tahap Proses keputusan Pembelian.

\section{Gaya Hidup}

Kotler dan Keller (2016: 192) mengemukakan bahwa pengertian Gaya hidup adalah pola hidup 
seseorang di dunia yang diekspresikan dalam aktivitas, minat, dan opininya. Gaya hidup menggambarkan keseluruhan diri seseorang dalam berinteraksi dengan lingkungannya. Gaya hidup menggambarkan seluruh pola seseorang dalam beraksi dan berinteraksi di dunia.

Menurut Luthans (2009), gaya hidup adalah pola hidup seseorang di dunia yang tercermin dalam kegiatan, minat, dan pendapat. Gaya hidup memotret interaksi "seseorang secara utuh" dengan lingkungannya. Gaya hidup adalah perilaku individu yang diwujudkan dalam bentuk aktifitas, minat dan pandangan individu untuk mengaktualisasikan kepribadiannya karena pengaruh interaksi dan lingkungannya Widjaya (2009).

Untuk melihat bagaimana gaya seorang atau pun sekelompok orang dapat diamati dari tempat tinggal maupun bentuk interaksi yang dilakukan setiap wargannya, baik dalam suatu perkampungan maupun lingkungan dimana si individu melakukan sutu interaksi. Interaksi yang dimaksud adalah interaksi yang dilakukan oleh satu individu dengan individu lain yang sangat dipengaruhi oleh perkembangan sikap dan perilaku individu tersebut. Dengan demikian sikap dan perilaku itu dapat membentuk suatu pola hidup yang khas dalam komunitas. Kehidupan yang demikian pada gilirannya akan memunculkan suatu bentuk gaya hidup. (Chaplin, 2005).

\section{Penelitian Terdahulu}

Penelitian terdahulu dapat digunakan untuk membentuk hipotesis atau jawaban sementara dalam penelitian ini, selain itu penelitian terdahulu dapat dipakai sebagai sumber pembanding dengan penelitian yang sedang penulis lakukan. Peneliti mengawali dengan menelaah penelitian terdahulu yang memiliki keterkaitan serta relevansi dengan penelitian yang dilakukan. Dengan demikian, peneliti mendapatkan rujukan pendukung, pelengkap serta pembanding yang memadai sehingga penulisan penelitian ini lebih memadai. Berikut beberapa penelitian terdahulu yang didapat dari dan internet sebagai bahan perbandingan agar diketahui persamaan dan perbedaannya. Judul penelitian yang diambil sebagai pembanding adalah yang memiliki variabel independen mengenai kelompok referensi dan gaya hidup sedangkan varibel dependen yaitu mengenai keputusan pembelian.

\section{METODE PENELITIAN}

\section{Lokasi dan Waktu Penelitian}

Lokasi penelitian ini dilakukan di Kota Dumai Jl. Sukajadi, No. 88A, Sukajadi, Dumai Kota Riau 28826.

\section{Jenis dan Sumber Data}

Jenis data yang digunakan pada penelitian ini adalah Data Primer dan Data Sekunder.

\section{Populasi dan Sampel}

Populasi dalam penelitian ini adalah Populasi dalam penelitian ini adalah 500 responden warga Kota Dumai yang membeli dan menggunakan sepeda motor Kawasaki D-Tracker 150.

Teknik penarikan sampel yang akan digunakan yaitu teknik sampling yang memberikan peluang yang sama bagi unsur populasi untuk dipilih menjadi anggota sampel. Dalam penelitian ini penulis 
menetapkan sampel sebanyak dengan kriteria-kriteria responden yaitu penduduk Kota Dumai yang membeli dan menggunakan sepeda motor Kawasaki D-Tracker 150, usia 17 tahun keatas. Sampel yang diambil dalam penelitian ini menggunakan rumus slovin dalam (Sudjarwo dan basrowi, 2009).

\section{Teknik Pengumpulan Data}

Metode pengumpulan data yang digunakan penulis dalam penelitian ini yaitu dengan menggunakan kuesioner Teknik pengukuran (teknik penskalaan) dalam kuesioner ini menggunakan Likert's Summated Rating (LSR), yaitu skala atau pengukuran sikap responden, jawaban pernyataan dinyatakan dalam pilihan yang mengakomodasi jawaban antara sangat setuju sampai sangat tidak setuju. Banyak pilihan biasanya tiga, lima, tujuh, Sembilan dan sebelas.

Pada tahap ini, pengumpulan data diperoleh melalui pengumpulan data dan informasi dengan melakukan kegiatan kepustakaan melalui buku-buku, jurnal, penelitian terdahulu dan lain sebagainya yang berkaitan dengan penelitian yang sedang dilakukan.

\section{Teknik Analisa Data}

Analisis data dalam penelitian ini menggunakan analisis kuantitatif dengan analisis jalur model dua tahap (two steppath analysis).

\section{IV.HASIL PENELITIAN \& PEMBAHASAN
Pengujian Koefisien Jalur Pengaruh Langsung

Pengujian hipotesis dan koefisien jalur pengaruh langsung antara variabel pengalaman kerja, disiplin, kepuasan kerja dan kinerja karyawan. Hasil pengaruh langsung dapat dilihat dari nilai koefisien jalur dan titik kritis yang signifikan pada $\alpha$ $=0.05$. hasil pengujian pengaruh langsung secara lengkap disajikan pada tabel 3 .

Tabel 3.

Keefisien Jalur Pengaruh Langsung dan Pengujian Hipotesis

\begin{tabular}{|l|c|c|c|c|c|}
\hline & $\begin{array}{c}\text { Original } \\
\text { Sample (O) }\end{array}$ & $\begin{array}{c}\text { Sample } \\
\text { Mean (M) }\end{array}$ & $\begin{array}{c}\text { Standard } \\
\text { Deviation } \\
\text { (STDEV) }\end{array}$ & $\begin{array}{c}\text { T Statistics } \\
(\mid \text { O/STDEV } \mid)\end{array}$ & $\begin{array}{c}P \\
\text { Values }\end{array}$ \\
\hline $\begin{array}{l}\text { Gaya Hidup -> } \\
\text { Keputusan Pembelian }\end{array}$ & 0.809 & 0.808 & 0.037 & 3.483 & 0.000 \\
\hline $\begin{array}{l}\text { Gaya Hudup -> } \\
\text { Kepuasan Konsumen }\end{array}$ & 0.682 & 0.683 & 0.066 & 5.529 & 0.000 \\
\hline $\begin{array}{l}\text { Keputusan Pembelian } \\
\text {-> Kepuasan } \\
\text { Konsumen }\end{array}$ & 0.180 & 0.179 & 0.071 & 2.941 & 0.011 \\
\hline
\end{tabular}

Sumber : Hasil Olahan 2020

Berdasarkan hasil penelitian, maka pengujian pengaruh langsung dan hipotesi penelitian bertujuan untuk menjawab apakah hipotesis yang

diajukan dapat diterima atau ditolak. Hasil pengujian hipotesis pengaruh langsung dapat dijelaskan sebagai berikut :

Uji Hipotesis 1 : Gaya Hidup berpengaruh signifikan terhadap Keputusan Pembelian

Pengujian hipotesis 1 (H1), bahwa gaya hidup berpengaruh signifikan terhadap keputusan 
pembelian, hal tersebut dibuktikan dengan pengujian statistik yang menunjukan nilai koefisien jalur (original sample estimate) sebesar 0.809 dan signifikan pada p-value $0.000(\mathrm{p}<\alpha=0.05)$. artinya bahwa gaya hidup berpengaruh signifikan terhadap keputusan pembelian dengan demikian hipotesis kesatu yang diajukan dalam penelitian ini dapat diterima.

Uji Hipotesis 2 : $\quad$ Gaya Hidup berpengaruh signifikan terhadap Kepuasan Konsumen.

Pengujian hipotesis $2(\mathrm{H} 2)$, bahwa gaya hidup berpengaruh signifikan terhadap kepuasan konsumen, hal tersebut dibuktikan dengan pengujian statistik yang menunjukan nilai koefisien jalur (original sample estimate) sebesar 0.682 dan signifikan pada $p$-value $0.000(\mathrm{p}<\alpha=0.05)$. artinya bahwa gaya hidup berpengaruh signifikan terhadap kepuasan konsumen dengan demikian hipotesis kedua yang diajukan dalam penelitian ini dapat diterima.

Uji Hipotesis 3 : Keputusan Pembelian berpengaruh signifikan terhadap Kepuasan Konsumen.
Pengujian hipotesis $3(\mathrm{H} 3)$, bahwa keputusan pembelian berpengaruh signifikan terhadap kepuasan konsumen, hal tersebut dibuktikan dengan pengujian statistik yang menunjukan nilai koefisien jalur (original sample estimate) sebesar 0.180 dan signifikan pada pvalue $0.0011(\mathrm{p}<\alpha=0.05)$. artinya bahwa keputusan pembelian berpengaruh signifikan terhadap kepuasan konsumen dengan demikian hipotesis ketiga yang diajukan dalam penelitian ini dapat diterima.

\section{Pengujian Koefisien Jalur Pengaruh Variabel tidak langsung Pemeriksaan pengaruh} variabel path analisis bertujuan untuk melihat pengaruh tidak langsung. Pendekatan Partial Least Square (PLS) dalam mengidentifikasi pengaruh variabel jalur dapat dilakukan melalui metode pemeriksaan nilai koefisien dan tingkat signifikansi. Dari metode pemeriksaan nilai koefisien dan signifikansi maka pengujian hipotesis dan koefisien jalur pengaruh variabel moderasi disajikan pada tabel 4.18 sebagai berikut :

Tabel 4.

Koefisien Jalur Pengaruh tidak langsung dan Pengujian Hipotesis

\begin{tabular}{|l|c|c|c|c|c|}
\hline & $\begin{array}{c}\text { Original } \\
\text { Sample }(\boldsymbol{O})\end{array}$ & $\begin{array}{c}\text { Sample Mean } \\
(\boldsymbol{M})\end{array}$ & $\begin{array}{c}\text { Standard Deviation } \\
(\text { STDEV })\end{array}$ & $\begin{array}{c}\text { T Statistics } \\
(\mid \text { O/STDEV })\end{array}$ & $\begin{array}{c}\boldsymbol{P} \\
\text { Values }\end{array}$ \\
\hline $\mathbf{X}>\mathbf{Z}$ & & & & & \\
\hline $\mathbf{X}>\mathbf{Y}$ & 0.410 & 0.009 & 0.014 & 3.731 & 0.001 \\
\hline $\mathbf{Z}>>\mathbf{Y}$ & & & & & \\
\hline
\end{tabular}

Sumber : Hasil Olahan 2020

Uji Hipotesis 4 :

Hidup berpengaruh terhadap Kepuasan dengan melalui Pembelian.
Gaya signifikan Konsumen Keputusan
Pengujian hipotesis $4(\mathrm{H} 4)$, bahwa gaya hidup berpengaruh signifikan terhadap kepuasan konsumen dengan melalui keputusan pemelian, hal tersebut dibuktikan 
dengan pengujian statistik yang menunjukan nilai koefisien jalur (original sample estimate) sebesar 0.410 dan signifikan pada $\mathrm{p}$-value $0.001(\mathrm{p}<\alpha=0.05)$. artinya bahwa dengan adaanya gaya hidup yang pola hidup seseorang di dunia yang diekspresikan dalam aktifitas, minat dan opininya sehingga menggambarkan keseluruhan diri seseorang yang berinteraksi dengan lingkungannya hal ini tentunya akan memberikan kepuasan tersendiri bagi konsumen, jika konsumen merasakan kepuasan tentunya akan memutuskan untuk membeli kembali sesuai dengan gaya hidupnya, dengan demikian hipotesis keempat yang diajukan dalam penelitian ini dapat diterima.

\section{PEMBAHASAN}

\section{Gaya Hidup terhadap Keputusan Pembelian}

Hasil dalam penelitian ini bahwa Gaya Hidup berpengaruh positif signifikan terhadap Keputusan Pembelian. Hal ini dibuktikan dengan hasil pengujian statistik yang menunjukan nilai koefisien jalur (original sample estimate) sebesar 0.809 dan signifikan pada $p$-value $0.000(\mathrm{p}<\alpha=0.05)$. artinya bahwa gaya hidup berpengaruh signifikan terhadap keputusan pembelian dengan demikian hipotesis kesatu yang diajukan dalam penelitian ini dapat diterima. Dengan ini memberikan gambaran bahwa semakin tingginya gaya hidup seseorang akan semakin mempengaruhi keputusan pembeliannya. Dalam teori Kotler 2013 mengatakan bahwa gaya hidup adalah pola hidup yang mengambarkan kegiatan, ketertarikan dan opini individu yang berinteraksi dengan lingkungan sekitarnya dan cara mengukurnya dengan cara mengunakan psicografics. Penggunaknaan aspek gaya hidup pada konsumen dapat dilakukan dengan sikap, keterkaitan dan pendapat konsumen. Jadi, sikap tertentu yang dimiliki oleh konsumen terhadap suatu objek tertentu bisa mencerminkan gaya hidupnya, gaya hidup seseorang juga bisa dilihat pada apa yang disenangi dan disukainya.

Hasil dalam penelitian ini sejalan dengan penelitian yang dilakukan oleh Chaudary et. al., (2014) terhadap 221 responden dengan teknik analisis Structural Equation Modeling menunjukan bahwa gaya hidup berpengaruh positif dan signifikan, hal ini dilatar belakangi bahwa sebagian besar responden berasal dari kelompok pendapatan yang lebih tinggi yang mengakibatkan harga tidak menjadi faktor penting dalam melakukan keputusan pembelian. Hal ini sejalan dengan penelitian yang dilakukan oleh Berdi dan Anisa (2016) yang mengatakan gaya hidup berpengaruh positif dan signifikan terhadap keputusan pembelian.

\section{Gaya Hidup terhadap Kepuasan Konsumen.}

Hasil dalam penelitian ini bahwa Gaya Hidup berpengaruh positif signifikan terhadap Keputusan Pembelian. Hal ini dibuktikan dengan hasil pengujian statistik yang menunjukan nilai koefisien jalur (original sample estimate) sebesar 0.682 dan signifikan pada $p$-value $0.000(\mathrm{p}<\alpha=0.05)$. artinya bahwa gaya hidup berpengaruh signifikan terhadap kepuasan konsumen dengan demikian hipotesis kedua yang diajukan dalam penelitian ini dapat 
diterima. Artinya semakin tinggi gaya hidup yang dimiliki seseorang akan memberikan tingkat kepuasan yang tinggi pulak sehingga untuk membeli suatu produk tidak menjadi masalah ketika ia merasakan kepuasan dalam produk tersebut. Dalam teori Kotler dan Keller (2009) yaitu konsumen yang sangat puas biasanya akan tetap setia untuk waktu yang lebih lama, membeli lagi ketika perusahaan memperkenalkan produk baru dan memperbaharui produk yang lama, membicarakan hal-hal baik tentang perusahaan dan produknya kepada orang lain dan tidak terlalu sensitif terhadap harga.

Dalam penelitian ini sejalan dengan penelitian yang dilakukan oleh Achmad Fernandes, Solimu (2016), mengatakan Gaya hidup berpengaruh signifikan terhadap kepuasan pelanggan dikarenakan gaya hidup mempunyai peranan penting dalam proses pengambilan keputusan yaitu peranan aktivitas, ketertarikan dan opini adalah membantu para pembeli untuk memutuskan cara memperoleh manfaat atau utilitas. Pelanggan akan merasakan kepuasan apabila perusahaan bisa mempertahankan kepuasan dengan cara memperbaiki serta menjaga kualitas produk dan kualitas layanan yang ada, serta lebih jeli dalam hal penetapan suatu harga.

\section{Keputusan Pembelian terhadap Kepuasan Konsumen.}

Hasil dalam penelitian ini bahwa keputusan pemelian berpengaruh positif signifikan terhadap kepuasan konsumen. Hal ini dibuktikan dengan hasil statistik yang menunjukan nilai koefisien jalur (original sample estimate) sebesar 0.180 dan signifikan pada $\mathrm{p}$ value $0.0011(\mathrm{p}<\alpha=0.05)$. artinya bahwa keputusan pembelian berpengaruh signifikan terhadap kepuasan konsumen dengan demikian hipotesis ketiga yang diajukan dalam penelitian ini dapat diterima. Menurut Kotler \& Amstrong (2014), keputusan pembelian adalah tahap dalam proses pengambilan keputusan pembeli di mana konsumen benar-benar membeli.

Dalam penelitian ini sejalan dengan hasil penelitian yang dilakukan oleh Syariffudin (2017) yang menyatakan bahwa variabel nilai pelanggan dan keputusan pembelian mempunyai pengaruh secara positif dan signifikan terhadap kepuasan pelanggan. Dapat diartikan bahwa semakin tinggi adanya nilai pelanggan, semakin tinggi pula tingkat kepuasan pelanggan untuk melakukan pembelian suatu produk dan jasa dan akan memutuskan utuk membeli kembali.

\section{Gaya Hidup terhadap Kepuasan Konsumen melalui Keputusan Pembelian.}

Hasil dalam penelitian ini bahwa keputusan pemelian mampu memediasi Gaya hidup berpengaruh positif signifikan terhadap kepuasan konsumen. Hal ini dibuktikan dengan hasil pengujian statistik yang menunjukan nilai koefisien jalur (original sample estimate) sebesar 0.410 dan signifikan pada $\mathrm{p}$-value $0.001(\mathrm{p}<\alpha=0.05)$. artinya bahwa dengan adaanya gaya hidup yang pola hidup seseorang di dunia yang diekspresikan dalam aktifitas, minat dan opininya sehingga menggambarkan keseluruhan diri seseorang yang berinteraksi dengan lingkungannya hal ini tentunya akan memberikan kepuasan tersendiri bagi konsumen, jika konsumen merasakan 
kepuasan tentunya akan memutuskan untuk membeli kembali sesuai dengan gaya hidupnya.

Hasil dalam penelitian ini sejalan dengan penelitian yang dilakukan oleh Beri (2017) dan Zikri (2011) yang mengatakan mengatakan gaya hidup berpengaruh signifikan terhadap keputusan pelanggan dengan keputusan pembelian sebagai mediasi. Hal ini dikarenakan jika gaya hidup konsumen yang baik akan memberikan pengaruh yang cukup besar terhadap kepuasan pelanggan sedangkan pelanggan akan merasa puas dengan kualitas yang diberikan. Penelitian menurut Zhiun (2011), mengatakan gaya hidup dan tempat berpenaruh terhadap keputusan pelanggan dank an memutuskan untuk membeli kembali.

\section{SIMPULAN DAN SARAN Simpulan}

1. Gaya Hidup berpengaruh positif dan signifikan terhadap Keputusan Pembelian. artinya bahwa dengan adaanya gaya hidup yang pola hidup seseorang dalam pekerjaanya sudah baik dan mapan yang diekspresikan dalam aktifitas, minat dan opininya akan mempengaruhi keputusan pembelian.

2. Gaya Hidup berpengaruh positif dan signifikan terhadap Kepuasan Konsumen. Artinya dengan gaya hidup selalu berkaitan dengan upaya untuk membuat diri eksis dalam cara tertentu dan berbeda dari kelompok akan terjadniya suatu perilaku konsumsi yang merupakan dampak dari perkembangan zaman, dimana individu mengalami rasa kepuasan terhadap dirinya.

3. Keputusan Pembelian berpengaruh positif dan signifikan terhadap Kepuasan Konsumen. Artinya keputusan pembelian dalam proses pengambilan keputusan pembeli di mana konsumen benar-benar membeli dikarenakan produk yang ia pakai dapat memuaskan dirinya.

4. Terdapat pengaruh yang tidak langsung Gaya Hidup terhadap Kepuasan Konsumen melalui Keputusan Pembelian. artinya kepuasan konsumen tidak srta merta bisa dapat merubah gaya hidup seseorang, teteapi jika sudah adanya keputusan untuk membeli makan konsumen sudah mendapatkan kepuasan didalam dirinya

\section{Saran}

Berdasarkan kesimpulan di atas, maka dapat diberikan beberapa saran sebagai berikut:

1. Untuk gaya hidup perusahaan Sepeda Motor Kawasaki DTracker 150 tak harus menggunakan Unitrack Single Shock dengan lima penyetelan kekerasan. Karena dengan hal itu bisa berkendara di segala medan menjadi lebih luwes ketimbang motor kebanyakan dan harusnya menggunakan basis mesin single 4 tak 150 cc dengan karburator KEIHIN NCV 24. Kompisisi ini membuat Motor Kawasaki D-Tracker 150 menjadi lebih 
irit dan ekonomis. Kawasaki

D-Tracker sudah menggunakan teknologi KSAI (Kawasaki Secondary Air Injection System). Teknologi ini membuat menjadi ramah lingkungan, dengan emisi gas buang sesuai standar EURO. DTracker menggunakan ban yang lebih ramah dengan jalan raya.

2. Untuk kepuasan konsumen perusahaan harus mampu membuat Kawasaki DTracker 150 sebagai pilihan produk sepeda motor sport yang tepat bagi konsumen dan menyesuaikan harga onderdil-onderdil sepeda motor dengan kualitas yang dihasilkan, mampu membuat dan memodifikasi produk yang unik dan berbeda sehingga konsumen merasa Kawasaki D-Tracker 150 berbeda dengan merek Kawasaki sebelumnya yang ditemukan sehingga konsumen tidak akan menggantikan Kawasaki DTracker 150 dengan sepeda motor sport merek lain.

3. Untuk keputusan pembelian perusahaan harus membuat agar dengan memakai sepeda motor Kawasaki D-Tracker 150 konsumen merasa lebih mudah untuk menjalankan aktivitasnya sehari-hari, dengan cara menampilkan iklan yang menarik dan sesuai sebagai salah satu upaya dalam meyakinkan konsumen bahwa D-Tracker 150 merupakan sepeda motor sport yang tidak kalah saing dengan sepeda motor model lain dalam memenuhi kebutuhan transportasi.

\section{DAFTAR PUSTAKA}

Keller, Kevin Lane. 2011. Strategic Brand Management : Building,Measuring, And Managing Brand Equity. Second Edition. Pearson Prentice Hal, New Jersey.

Kotler dan Armstrong. 2011. PrinsipPrinsip Pemasaran. Jilid 1 Edisi 8. Jakarta: Erlangga.

Kotler dan Armstrong. 2013. Dasardasar Pemasaran Jilid 1 Edisi Kesembilan. Jakarta: PT. Indeks Gramedia.

Kotler, Philip. 2009. Manajemen Pemasaran (Edisi Kesebelas). Jakarta: PT.Indeks Kelompok Gramedia.

Kotler dan Armstrong. 2014. PrinsipPrinsip Pemasaran Jilid 1 Edisi 12. Penerbit Erlangga. Jakarta.

Kotler, Philip. 2005. Manajemen Pemasaran Jilid 1 dan 2. Jakarta: PT. Indeks Kelompok Gramedia.

Kotler, Philip. 2013. Manajemen Pemasaran, Analisis Perencanaan, Pengendalian, Prentice Hall, Edisi Bahasa Indonesia. Jakarta: Salemba Empat.

Kotler dan Keller. 2013. Manajemen Pemasaran Jilid II Edisi Keduabelas. Jakarta: PT Indeks Gramedia. 
Kotler \& Keller. 2011. Manajemen

Pemasaran Jilid II Edisi

Ketigabelas. Penerbit

Erlangga. Jakarta.

Kotler, Kevin Lane (2008).

Manajemen Pemasaran. Edisi

13 Jilid 2. Jakarta: Penerbit

Erlangga.

Kotler, Philip (2013). Manajemen Pemasaran. Edisi Millenium. Jakarta: PT Prenhalindo Indonesia.

Kotler, Philip and Gary Armstrong. 2012. Principles of Marketing. New Jersey: Pearson Education Limited.

Kotler dan Keller. 2009. Manajemen Pemasaran Edisi 13 Jilid 1. Jakarta: Erlangga

Kotler dan Keller. 2009. Manajemen Pemasaran Edisi 13 Jilid 2. Jakarta: Erlangga

Schiffman, L.G. dan Kanuk. L.L. (2014). Perilaku Konsumen (Edisi Ketujuh). Jakarta: PT. Indeks Kelompok Gramedia. 